\title{
Predictors and Risk Perceptions of Using Cell Phones while Driving among Young Adult Drivers
}

\author{
Scarlett Mia S. Tabuñar \\ Department of Emergency Medicine, University of the Philippines-Philippine General Hospital, UP-College of Medicine, Manila \\ 1000, Philippines
}

\begin{abstract}
The Philippines is expecting a rise in the number of drivers that use mobile phones while driving. It is known as the "texting capital of the world". The objectives of this study were to determine the predictors, risk perceptions and the prevalence of cell phone use while driving among trainee residents of the University of the Philippines-Philippine General Hospital. This cross-sectional study employed total enumeration. A survey was first distributed to the target population, followed by a focus group discussion. Chi-square and multiple logistic regression were used to analyze data. Included in the final analysis were 175 drivers aged 25-30 years (mean $=$ $27.90 \pm 1.34)$. There was no significant difference in the risk perceptions of cell phone users vs. non-users, and most perceived hands-free devices safer to use $(p=0.030)$. The reported prevalence is $90.68 \%$; drivers have a significant overall unsafe attitude $(p=$ $0.007)$, and an unsafe attitude when using handsets when driving, even when this is known to be dangerous $(p=0.003)$. In conclusion, driving with hands-free devices was perceived to be safer, although drivers have a high overall unsafe attitude. Driving for more than two years and having an unsafe attitude were found to be significant predictors of cell phone use while driving. Countermeasures must take into account these factors when instituting behavioral modification strategies and road safety policies concerning unsafe and distracted driving.
\end{abstract}

Key words: Attitude, cell phone use while driving, driving experience, distracted driving, risk perceptions, young adult drivers.

\section{Introduction}

Distracted driving (DD) is one of the key factors cited by the WHO (World Health Organization) that needs to be addressed by governments in order to prevent RTI (road traffic injuries) [1]. The CDC (Centers for Disease Control and Prevention) defines distracted driving as any activity that takes a person's attention away from the primary task of driving. Activities such as using cell phones, texting, utilizing navigation technologies (GPS) and eating are all considered distractions which could endanger road users' safety [2]. There are three main forms of distraction while driving: manual, visual and cognitive. Manual distraction involves taking one's hands off the steering wheel while visual distraction occurs when the

Corresponding author: Scarlett Mia S. Tabuñar, MD, associate professor, research fields: emergency medicine, road safety, health education and promotion. driver's eyes are taken off the road. Cognitive distraction, on the other hand, happens when the individual's focus is not directly on the act of driving, causing his or her attention to wander [2]. Of particular public health interest, due to the advent of technology, is texting and talking on mobile phones while driving, as they pose the most significant and real danger by combining all three types of DD [3]. Several studies show that the distraction caused by hand-held phones could impair driving performance, e.g. longer reaction times (notably braking, and reaction time, also reaction to traffic signals), impaired ability to keep in the correct lane, and shorter following distances, resulting in overall reduction in awareness of the driving situation [4]. Cell phone use while driving increases the likelihood of a road crash by four-fold [5]. Simulation studies report that this type of distraction could cause a similar decrement in driving performance to a person with a 0.8 percent blood alcohol level, the point at 
which drivers are generally considered intoxicated [6]. Hands-free devices (e.g. earphones, speaker-phones, Bluetooth, etc.) do not appear to minimize the deleterious effects of $\mathrm{DD}$, as evidence reveals that hands-free cell phone road users execute the tasks of driving with the same diminution in ability as those who do not $[7,8]$.

The 2014 NHTSA (National Highway Traffic Safety Administration) report on distracted driving estimates that $71 \%$ of teens and young drivers compose and send text messages, and $78 \%$ read short message services [9]. An alarming statistic reveals an increase of drivers' text-messaging or visibly manipulating handheld devices from $1.7 \%$ in 2013 to $2.2 \%$ in 2014 , with young drivers (age 16 to 24 ) using electronic devices at higher rates [9]. Distracted driving, particularly through mobile phone use, is much more common among young adult drivers (under 30 years of age) [10]. In the Philippines the NSCB (National Statistics Coordination Board) reports that from 2001-2006 the highest spike in the cause of road traffic crash of more than five times is due to cell phone use, which ranked 12th amongst the most common cause of traffic accidents in 2006 [11]. More than 70 countries worldwide enforce restrictions and bans on the use of mobile phones while driving [12], it was only on July 2015 that the Philippines enacted the Republic Act 10913, or Anti Distracted Driving Act, defining and penalizing distracted driving. Under the new law, "distracted driving" is defined as "using a mobile communications device to write, send, or read a text-based communication or to make or receive calls", and "using an electronic entertainment or computing device to play games, watch movies, surf the Internet, compose messages, read e-books, perform calculations, and other similar acts" [13]. As most of the evidence for distracted driving comes from research performed in industrialized countries, there is a dearth of local literature investigating the extent of the problem, particularly in young adult drivers. It is therefore the aim of this study to determine the predictors, risk perceptions and the prevalence of distracted driving among young doctors training at the UP-PGH (University of the Philippines-Philippine General Hospital), aged under 30 years, who use cell phones, for both text-messaging and conversing while driving.

\section{Methodology}

The study is a mixed method undertaken in two stages: first, cross-sectional survey questionnaires were distributed to the target population of young adult drivers followed by a FGD (focus group discussion), with one of the identified resident groups via convenience sampling who were available for the activity. The main purpose of which was to gather a more detailed information on the topic.

The tool questionnaires were given to all (1st to 5 th year) the residents at UP-PGH. Total enumeration was employed in order to capture the subset of drivers in the study population. The trainee residents were chosen for their ages, which fall within the 24-30 year-old range, well within the age group of interest. It was conducted over a two month period, from July to August 2017. The total number of residents hired by UP-PGH at the start of the year was 533 according to the Human Resource Department of the hospital. Non-drivers, drivers aged 31 and above, and those who did not agree to participate in the study, were excluded. Ethics approval came from UP-Manila Research Ethics Board (UPM-REB-2017-149-01), which was secured prior to the start of the study, and informed consent for the survey was waived, as the self-administered questionnaire was anonymized in order to protect the privacy of respondents. However, it was accordingly secured for the FGD.

The structured questionnaire was developed based on the objectives of the study, a review of the related literature $[12,14]$, and constructed in a way that is more apt to the local setting. It consisted of four sections, namely socio-demographic profile, risk perceptions, distracted driving behaviour survey and attitude toward distracted driving. It was distributed by 
a research assistant to the residents either during one of the departmental conferences, or at any preferred time of their convenience. The socio-demographic profile part had five questions and an added item of inquiry about the knowledge of the Anti-Distracted Driving Law penalizing the act. The section on risk perceptions had four questions on the use of hands-free devices, the dangers of cell phone use that can result in collisions, and cell phone use being just as dangerous as alcohol-impaired driving. Responses were based on a five-point Likert scale (with $1=$ Strongly Disagree, 2 = Disagree, $3=$ Neutral, $4=$ Agree, $5=$ Strongly Agree). In order to differentiate the perceptions of risk, responses were collapsed into to two categories: safe risk perception was defined as Likert scales that agreed with statements complying with established national laws on distracted driving. According to Distracted Driving Act (RA 10913), a motorist engaging in any of the following acts in a motor vehicle in motion or temporarily halted at a red light, whether diplomatic, public or private, is considered unlawful: (a) using a mobile communications device to write, send or read a text-based communication or to make or receive calls, and other similar acts; and (b) using an electronic entertainment or computing device to play games, watch movies, surf the internet, compose messages, or read e-books [13]. Those responses, under the Likert scale that were contrary to the Distracted Driving Act, including "neutral" answers, were considered unsafe risk perceptions.

The distracted driving survey focusing only on cell phone use while driving was adopted and modified from a version of the 11-item Distracted Driving Survey of Bergmark et al. It is a validated tool measuring cell phone-related distracted driving for drivers age 24 and below [15]. This section has four (4) questions concerning cell phone and hands-free device use, and asked whether the resident had used their mobile phone to view other mobile phone applications such as maps, directions and social media while driving during the previous 30 days; the response was binary, recorded either yes or no.

Finally, five (5) questions on attitudes towards cell phone use during driving were modelled after the questions used by Harrison in order to evaluate college students' perceptions of text messaging while driving [14]. The response was similar to that for risk perception using the same description of a 5-point Likert scale, and interpretation was similarly divided into two groups: safe attitudes (Likert scales in agreement with DD Laws) and unsafe attitudes (Likert scales, including "neutral", that went against DD Laws).

The FGD topics were guided by several reports from countries that have extensively studied and made progress in addressing risky driving behavior, particularly distracted driving by using handphones [11, $16,17]$. The principal investigator conducted the FGD among residents of the DEM (Department of Emergency Medicine). The FGD explored the issues and constructs included in the structured survey.

Socio-demographic data and qualitative data were encoded in Microsoft Excel and analysed using STATA V12. A summary of the descriptive data was tabulated through graphic presentation. Chi-square was used to determine the associations between the variables of interest. A univariate comparison was performed on the socio-demographic data, risk perceptions and attitudes, which identified the significant variables $(p<0.05)$. Multiple logistic regression was then utilized to ascertain the predictors of cell phone use while driving. An odds ratio with a 95\% confidence interval was used as the summary statistics.

\section{Results}

A total of 393 residents answered the survey out of the 533 residents but only 175 drivers $(44.52 \%)$ aged 25-30 years were included in the analysis, which satisfied the inclusion criteria. The mean age of the driving respondents was $27.90 \pm 1.34$, the youngest being 25 and the oldest 30 . More than half (54.29\%) were men and $52.98 \%$ were in the combined mid-range 
annual family income of P100, 001 to $\mathrm{P} 1$ million ( USD 1,935 to USD 19,357). One hundred and two doctors $(58.96 \%)$ admitted being involved in a road traffic accident (RTA), mostly as drivers (42.86\%), while $26.37 \%$ were involved as passengers, and $30.77 \%$ as both. The socio-demographic profile of the driving residents is summarized in Table 1.

Regarding driving experience, $85.55 \%$ had been driving for more than two years, and a considerable percentage $(94.29 \%)$ of respondents knew that distracted driving is penalized under the anti-distracted driving law.

The overall risk perception of mobile phone use during driving had no significant findings amongst either users or non-users. However, more drivers who used cell phones perceived using hands-free devices to be safer ( $p=0.030$ ) (Table 2). Results showed that a considerable proportion of residents $(65.22 \%)$ sent or read a texts, called or answered a call while, while a more significant percentage $(84.47 \%)$ accessed their handsets to view maps, directions or navigation applications. More than half (55.90\%) of respondents used hands-free devices such as earphones, speakerphones, Bluetooth devices, etc., while behind the wheel and $49.69 \%$ viewed and read messages on social media sites via their phone while driving (Table 3).

Not all respondents answered all the questions resulting in missing values on a number of items; the proportion of missing data is relatively small thus they were omitted in the final analysis. Overall reported cell phone usage was 146 or $90.68 \%$ out of the only 161 residents who registered a response on self-reported cell phone use. The mean age was $27.39 \pm 1.34$, with more males $(56.85 \%)$ who engaged on this distracting activity, while $40 \%$ had an annual family income of more than P1 million ( > USD 19,357). More than half or $59.72 \%$ were involved in a road traffic crash mostly as a driver (42.67\%), and a considerable percentage $(87.59 \%)$ were driving for more than two years. Only 7 $(4.79 \%)$ of the 146 cell phone users admitted not knowing the implementation of the "Anti-Distracted

Table 1 Socio-demographic profile of drivers.

\begin{tabular}{lll}
\hline Data & & $n=175$ \\
\hline 1. Age (years) & & $\begin{array}{c}\text { Mean: } 27.90 \pm 1.34 \\
\text { (min }=25 ; \max =30)\end{array}$ \\
\hline & Number & 54.29 \\
\hline 2. Sex & 95 & 45.71 \\
Male & 80 & 9.52 \\
Female & 16 & 26.19 \\
3. Annual family income (USD 1= Php 51.66)* & 44 & 26.79 \\
P100,000 and less (< USD1,935) & 45 & 37.50 \\
P100,001 to P500,000 (USD1,935-9,679) & 63 & 41.04 \\
P500,001 to P1,000,000 (USD-9,679-19,357) & 71 & 58.96 \\
P1,000,001 and above (> USD 19,357) & 102 & 42.86 \\
4. Involvement in RTC & 39 & 26.37 \\
No & 24 & 30.77 \\
Yes & 28 & 14.45 \\
As driver & 25 & 85.55 \\
As passenger & & 94.29 \\
Both & 148 & 5.71 \\
Driving for how many years? & 165 & \\
>2 & 165 & \\
6. Do you know that distracted driving is penalized under the & & \\
Yes & & \\
No & & \\
\hline
\end{tabular}

*Conversion rate of US dollar to Philippine peso as 28 Oct 2017. 
Table 2 Frequency of and risk perception of cell phone use while driving: cell phone users vs. non-users.

\begin{tabular}{|c|c|c|c|c|c|c|c|c|c|}
\hline \multirow{3}{*}{ Items } & \multicolumn{4}{|c|}{ Drivers using cellphone } & \multicolumn{4}{|c|}{ Drivers NOT using cellphone } & \multirow{3}{*}{$p$-value } \\
\hline & \multicolumn{2}{|c|}{$\begin{array}{l}\text { Safe risk perception } \\
\text { (Likert scales in } \\
\text { agreement with } \\
\text { Anti-DD Laws) }\end{array}$} & \multicolumn{2}{|c|}{$\begin{array}{l}\text { Unsafe risk } \\
\text { perception } \\
\text { (Likert scales } \\
\text { contrary to Anti-DD } \\
\text { Laws including } \\
\text { neutral) }\end{array}$} & \multicolumn{2}{|c|}{$\begin{array}{l}\text { Safe risk perception } \\
\text { (Likert scales in } \\
\text { agreement with } \\
\text { Anti-DD Laws) }\end{array}$} & \multicolumn{2}{|c|}{$\begin{array}{l}\text { Unsafe risk } \\
\text { perception } \\
\text { (Likert scales } \\
\text { contrary to Anti-DD } \\
\text { Laws including } \\
\text { neutral) }\end{array}$} & \\
\hline & $\bar{n}$ & $\%$ & $n$ & $\%$ & $n$ & $\%$ & $n$ & $\%$ & \\
\hline $\begin{array}{l}\text { 1. Hands-free devices are safe to } \\
\text { use when driving }\end{array}$ & 16 & 11.03 & 129 & 88.97 & 5 & 33.33 & 10 & 66.67 & 0.030 \\
\hline $\begin{array}{l}\text { 2. Cellphone use is NOT always } \\
\text { dangerous while driving }\end{array}$ & 85 & 58.22 & 61 & 41.78 & 12 & 80.00 & 3 & 20.00 & 0.101 \\
\hline $\begin{array}{l}\text { 3. Cellphone use will more likely } \\
\text { result in a road crash/collision? }\end{array}$ & 118 & 81.38 & 27 & 18.62 & 14 & 93.33 & 1 & 6.67 & 0.473 \\
\hline $\begin{array}{l}\text { 4. Cellphone use is as dangerous } \\
\text { as alcohol-impaired driving? }\end{array}$ & 88 & 60.27 & 58 & 39.73 & 9 & 60.00 & 6 & 40.00 & 0.984 \\
\hline $\begin{array}{l}\text { OVERALL risk perception of } \\
\text { distracted driving }\end{array}$ & 13 & 9.03 & 131 & 90.97 & 4 & 26.67 & 11 & 73.33 & 0.059 \\
\hline
\end{tabular}

Table 3 Frequency of drivers who use cell phones while driving.

\begin{tabular}{|c|c|c|c|c|}
\hline \multirow{2}{*}{$\begin{array}{l}\text { Items } \\
\text { In the last } 30 \text { days? }\end{array}$} & \multicolumn{2}{|c|}{ Yes } & \multicolumn{2}{|c|}{ No } \\
\hline & $\bar{n}$ & $\%$ & $n$ & $\%$ \\
\hline $\begin{array}{l}\text { 1. Did you use your cellphone while driving (including texting, reading text, } \\
\text { calling or receiving call)? }\end{array}$ & 105 & 65.22 & 56 & 34.78 \\
\hline $\begin{array}{l}\text { 2. Do you use hands-free devices when using your cellphone while driving } \\
\text { (e.g. earphones, speaker phone, Bluetooth)? }\end{array}$ & 90 & 55.90 & 71 & 44.10 \\
\hline $\begin{array}{l}\text { 3. Have you used your cellphone to view maps, directions or navigation apps } \\
\text { while driving (e.g. google map, Waze, GPS etc.)? }\end{array}$ & 136 & 84.47 & 25 & 15.53 \\
\hline $\begin{array}{l}\text { 4. Have you used your cellphone to view or read messages on social apps or } \\
\text { sites while driving (e.g. Facebook, Twitter, Instagram, Snapchat etc.)? }\end{array}$ & 80 & 49.69 & 81 & 50.31 \\
\hline
\end{tabular}

Driving Law" (Table 4). Only driving experience of more than two years $(p=0.002)$ had a significant association with handheld phone use while driving among the study participants.

Comparative analysis showed that drivers who engaged in this type of distracted activity had significantly higher overall unsafe attitudes vis-a-vis to those who did not $(p=0.007)$, and the same result was noted for unsafe attitudes of those using handsets, even when the drivers knew it was dangerous to do so while driving a vehicle $(p=0.003)$ (Table 5).

The preliminary results of the univariate logistic regression analysis revealed risk perception $(p=0.046)$, years of driving $(p=0.001)$ and attitude $(p=0.005)$ as possible predictors of cell phone use while driving (see Table 6 for the univariate logistic regression results).

Model building using multiple logistic regression that sequentially omits the variable that had the highest $p$-value identified predictors. The final model showed that attitude and more than two years of driving as significant predictors of cell phone use while driving. (see Table 7 for multiple logistic regression results).

\subsection{Key Findings of the Focus Group Discussion}

The principal investigator facilitated the FGD via convenient sampling among residents of the DEM following one of their academic activities. Topics included in the discussion were risk perception, attitudes and the socio-demographic profile that influenced handheld phone use in young adult drivers. A more in-depth approach was employed in order to gain more specific and detailed information. The objective of the discussion was to acquire untapped insights into distracted driving, particularly concerning cell phone use. It also aimed to gather sentiments, inputs, and opinions that may not have been captured 
Table 4 Association of drivers who use cell phones while driving, to a socio-demographic profile.

\begin{tabular}{|c|c|c|c|c|}
\hline Data & \multicolumn{4}{|l|}{$n=146$} \\
\hline \multirow[t]{2}{*}{ 1. Age } & \multicolumn{4}{|c|}{ Mean: $27.39 \pm 1.34(\min =25 ; \max =30)$} \\
\hline & & $\mathrm{n}$ & $\%$ & $p$-value \\
\hline \multirow{3}{*}{ 2. Gender } & Male & 83 & 56.85 & \multirow{2}{*}{0.081} \\
\hline & Female & 63 & 43.15 & \\
\hline & P100,000 and less ( $<$ USD1,935) & 11 & 7.86 & \multirow{4}{*}{0.241} \\
\hline \multirow{3}{*}{$\begin{array}{l}\text { 3. Annual Family Income } \\
\text { (USD } 1=\text { Php 51.66) }\end{array}$} & $\mathrm{P} 100,001$ to $\mathrm{P} 500,000$ (USD1,935-9,679) & 35 & 25.00 & \\
\hline & P500,001 to P1,000,000 (USD-9,679-19,357) & 38 & 27.14 & \\
\hline & P1,000,001 and above (> USD 19,357) & 56 & 40.00 & \\
\hline \multirow[t]{5}{*}{ 4. Involvement in RTC } & Yes & 86 & 59.72 & \multirow{5}{*}{0.632} \\
\hline & As driver & 32 & 42.67 & \\
\hline & As passenger & 19 & 25.33 & \\
\hline & Both & 24 & 32.00 & \\
\hline & No & 58 & 40.28 & \\
\hline \multirow{2}{*}{ 7. Driving for how many years? } & $\leq 2$ & 18 & 12.41 & \multirow{2}{*}{0.002} \\
\hline & $>2$ & 127 & 87.59 & \\
\hline \multirow{2}{*}{$\begin{array}{l}\text { 8. Do you know that distracted driving is penalized } \\
\text { under the "Anti-Distracted Driving Law"? }\end{array}$} & Yes & 139 & 95.21 & \multirow{2}{*}{0.199} \\
\hline & No & 7 & 4.79 & \\
\hline
\end{tabular}

Table 5 Frequency of and attitude towards cell phone use while driving: cell phone users vs. not users.

\begin{tabular}{|c|c|c|c|c|c|c|c|c|c|}
\hline & \multicolumn{4}{|c|}{ DRIVERS using cell phone } & \multicolumn{4}{|c|}{ Drivers NOT using cell phone } & \multirow{3}{*}{$p$-value } \\
\hline & \multicolumn{2}{|c|}{$\begin{array}{l}\text { Safe attitude } \\
\text { (Likert scales in } \\
\text { agreement with } \\
\text { Anti-DD Laws) }\end{array}$} & \multicolumn{2}{|c|}{$\begin{array}{l}\text { Unsafe attitude } \\
\text { (Likert scales } \\
\text { contrary to } \\
\text { Anti-DD Laws } \\
\text { including neutral) }\end{array}$} & \multicolumn{2}{|c|}{$\begin{array}{l}\text { Safe attitude } \\
\text { (Likert scales in } \\
\text { agreement with } \\
\text { Anti-DD Laws) }\end{array}$} & \multicolumn{2}{|c|}{$\begin{array}{l}\text { Unsafe attitude } \\
\text { (Likert scales } \\
\text { contrary to Anti- } \\
\text { DD Laws } \\
\text { including neutral) }\end{array}$} & \\
\hline & $\bar{n}$ & $\%$ & $n$ & $\%$ & $n$ & $\%$ & $n$ & $\%$ & \\
\hline $\begin{array}{l}\text { It is unsafe to use a cell phone while } \\
\text { driving (including texting, reading texts, } \\
\text { calling or receiving calls? }\end{array}$ & 114 & 78.08 & 32 & 21.92 & 13 & 86.67 & 2 & 13.33 & 0.740 \\
\hline $\begin{array}{l}\text { It should be illegal to use a cell phone } \\
\text { while driving }\end{array}$ & 60 & 41.10 & 86 & 58.90 & 10 & 66.67 & 5 & 33.33 & 0.057 \\
\hline $\begin{array}{l}\text { Using a cell phone while driving can be } \\
\text { dangerous, so I won't do it }\end{array}$ & 68 & 46.58 & 78 & 53.42 & 13 & 86.67 & 2 & 13.33 & 0.003 \\
\hline $\begin{array}{l}\text { It is only me who will be affected if I want } \\
\text { to text while driving }\end{array}$ & 116 & 79.45 & 30 & 20.55 & 14 & 93.33 & 1 & 6.67 & 0.306 \\
\hline $\begin{array}{l}\text { Using a cell phone while driving is not } \\
\text { always distracting }\end{array}$ & 52 & 35.62 & 94 & 64.38 & 9 & 60.00 & 6 & 40.00 & 0.064 \\
\hline $\begin{array}{l}\text { OVERALL attitude on using cell phone } \\
\text { while driving }\end{array}$ & 22 & 15.07 & 124 & 84.93 & 7 & 46.67 & 8 & 53.33 & 0.007 \\
\hline
\end{tabular}

by the questionnaire. The discussion clarified some of the responses in the preliminary survey and identified salient factors relevant to the subject, which helped to analyse the results in a meaningful way.

Seven DEM residents consented to participate after an initial explanation of the intent of the activity; the group consisted of four males and three females belonging to all year levels of training. The whole discussion was audio-taped and lasted for 57 minutes.
It was a free-flowing discourse of ideas expressed in both the vernacular and in English.

\subsubsection{Driving Background of FGD Participants}

The driving history of the participants ranged from two to twenty years, driving motorcycle and cars, from 7 to 10 times per week and with most of them driving in a city traffic environment. Most admitted to have once been involved in a RTC (road traffic crash); five as drivers, one as a passenger and one as both; no one 
Table 6 Univariate logistic regression analysis predicting cell phone use while driving.

\begin{tabular}{|c|c|c|c|}
\hline & OR (odds ratio) & $95 \% \mathrm{CI}$ & $\begin{array}{l}p \text {-value } \\
p<0.05\end{array}$ \\
\hline 1 Age & 1.23 & $0.82-1.84$ & 0.324 \\
\hline \multicolumn{4}{|l|}{$\begin{array}{l}\text { 2. Gender } \\
(\text { male }=\text { ref })\end{array}$} \\
\hline female & 0.38 & $0.12-1.17$ & 0.091 \\
\hline \multicolumn{4}{|l|}{ 3. Annual Family Income } \\
\hline \multicolumn{4}{|l|}{$\mathrm{P} 100,000$ and less $(<\mathrm{USD} 1,935)=$ ref } \\
\hline $\mathrm{P} 100,001$ to P500,000 (USD1,935-9,679) & 0.53 & $0.06-4.90$ & 0.576 \\
\hline P500,001 to P1,000,000 (USD-9,679-19,357) & 0.86 & $0.09-8.54$ & 0.900 \\
\hline P1,000,001 and above (>USD 19,357) & 1.70 & $0.16-17.86$ & 0.660 \\
\hline \multicolumn{4}{|l|}{$\begin{array}{l}\text { 4. Involvement in RTC? } \\
(\text { No }=\text { ref) }\end{array}$} \\
\hline Yes & 1.30 & $0.45-3.77$ & 0.633 \\
\hline \multicolumn{4}{|l|}{ 5. Years of driving } \\
\hline \multicolumn{4}{|l|}{$\leq 2$ years (ref) } \\
\hline$>2$ years & 7.06 & $2.22-22.46$ & 0.001 \\
\hline \multicolumn{4}{|l|}{$\begin{array}{l}\text { 6. Knowledge about Anti-Distracted Driving Law } \\
(\text { No }=\text { ref })\end{array}$} \\
\hline Yes & 3.054 & $0.57-16.25$ & 0.190 \\
\hline \multicolumn{4}{|l|}{$\begin{array}{l}\text { 7. Risk perception } \\
\text { (Safe risk perception= Ref) }\end{array}$} \\
\hline Unsafe risk perception & 3.66 & $1.02-13.16$ & 0.046 \\
\hline \multicolumn{4}{|l|}{$\begin{array}{l}\text { 8. Attitude on using cell phone while driving } \\
\text { (Safe attitude }=\text { reference) }\end{array}$} \\
\hline Unsafe attitude & 4.93 & $1.62-14.98$ & 0.005 \\
\hline
\end{tabular}

received a police citation or traffic infraction.

3.1.2 Socio-demographic Differences of Risk Perceptions on Cell Phone Use while Driving

The insights gathered were that younger, male drivers with higher educational attainments and higher annual family incomes engaged more in distracted driving than their counterparts. Older and more experienced drivers were more careful, focused and vigilant when driving, knowing well that their reflexes were not as fast as when they were younger. Likewise, their years of experience taught them to be less distracted and non-complacent when driving. On the other hand, younger, less experienced drivers were more "techie", over-confident and agitated when driving. Young drivers used their mobile phones during long drives to prevent them from falling asleep on the road.

Male drivers were more prone to doing more things while driving, e.g. tinkering on the car stereo, compared to female drivers. Men were also more distracted and inattentive when driving, leading to difficulty in manoeuvring, when mistakes in spatial estimation occurred. Moreover, drivers with higher educational backgrounds and higher annual family incomes have a higher likelihood of possessing telecommunication devices, and are also likely to have more things preoccupying their minds, whether personal or occupation-related, resulting in greater cell phone use when driving. Drivers in the higher income bracket were obliged to answer work-related messages or calls.

3.1.3 The Prevalence of Distracted Driving Particularly through Cell Phone Use while Driving

This was high among the group, with or without hands-free devices, due to the utilization of navigational apps, e.g. Waze, maps etc.

3.1.4 Reasons for Cell Phone Use When Driving

Calls were usually answered or made to significant persons e.g. girlfriends, parents or workmates, with no particular preference whether the vehicle was moving 
Table 7 Summary of multiple logistic regression predicting use of cell phone while driving.

\begin{tabular}{|c|c|c|c|c|c|c|c|}
\hline Variable & $\begin{array}{l}\text { Full } \\
\text { Model } \\
\text { (All } \\
\text { Predictors) }\end{array}$ & $\begin{array}{l}\text { Model } \\
1\end{array}$ & $\begin{array}{l}\text { Model } \\
2\end{array}$ & $\begin{array}{l}\text { Model } \\
3\end{array}$ & $\begin{array}{l}\text { Model } \\
4\end{array}$ & $\begin{array}{l}\text { Model } \\
5\end{array}$ & $\begin{array}{l}\text { Model } \\
6\end{array}$ \\
\hline & $\begin{array}{l}\mathrm{OR} \\
\text { (p-value) }\end{array}$ & $\begin{array}{l}\text { OR } \\
\text { (p-value) }\end{array}$ & $\begin{array}{l}\text { OR } \\
\text { (p-value) }\end{array}$ & $\begin{array}{l}\text { OR } \\
\text { (p-value) }\end{array}$ & $\begin{array}{l}\text { OR } \\
\text { (p-value) }\end{array}$ & $\begin{array}{l}\text { OR } \\
\text { (p-value) }\end{array}$ & $\begin{array}{l}\text { OR } \\
\text { (p-value) }\end{array}$ \\
\hline Age & $\begin{array}{l}1.00 \\
(0.987)\end{array}$ & - & - & - & - & - & - \\
\hline \multicolumn{8}{|l|}{ Gender } \\
\hline Male (Reference) & - & - & - & - & - & - & - \\
\hline Female & $\begin{array}{l}0.74 \\
(0.657)\end{array}$ & $\begin{array}{l}0.74 \\
(0.656)\end{array}$ & $\begin{array}{l}0.70 \\
(0.576)\end{array}$ & $\begin{array}{l}0.68 \\
(0.543)\end{array}$ & - & - & - \\
\hline \multicolumn{8}{|c|}{ Annual Family Income } \\
\hline $\begin{array}{l}\text { P100,000 and less } \\
(<U S D 1,935)=\text { Ref }\end{array}$ & - & - & - & - & - & - & - \\
\hline $\begin{array}{l}\text { P100,001 to } \mathrm{P} 500,000 \\
\text { (USD1,935-9,679) }\end{array}$ & $\begin{array}{l}0.94 \\
(0.959)\end{array}$ & $\begin{array}{l}0.94 \\
(0.959)\end{array}$ & - & - & - & - & - \\
\hline $\begin{array}{l}\mathrm{P} 500,001 \text { to } \mathrm{P} 1,000,000 \\
\text { (USD-9,679-19,357) }\end{array}$ & $\begin{array}{l}2.85 \\
(0.431)\end{array}$ & $\begin{array}{l}2.85 \\
(0.431)\end{array}$ & - & - & - & - & - \\
\hline $\begin{array}{l}\text { P1,000,001 and above } \\
\text { (>USD 19,357) }\end{array}$ & $\begin{array}{l}2.26 \\
(0.526)\end{array}$ & $\begin{array}{l}2.26 \\
(0.523)\end{array}$ & - & - & - & - & - \\
\hline \multicolumn{8}{|l|}{ Involvement in RTC } \\
\hline No (Reference) & - & - & - & - & - & - & - \\
\hline Yes & $\begin{array}{l}1.43 \\
(0.597)\end{array}$ & $\begin{array}{l}1.43 \\
(0.597)\end{array}$ & $\begin{array}{l}1.11 \\
(0.870)\end{array}$ & - & - & - & - \\
\hline \multicolumn{8}{|l|}{$\begin{array}{l}\text { Knowledge about Anti- } \\
\text { Distracted Driving Law }\end{array}$} \\
\hline No (Reference) & - & - & - & - & - & - & - \\
\hline Yes & $\begin{array}{l}4.77 \\
(0.181)\end{array}$ & $\begin{array}{l}4.80 \\
(0.156)\end{array}$ & $\begin{array}{l}3.26 \\
(0.240)\end{array}$ & $\begin{array}{l}3.09 \\
(0.250)\end{array}$ & $\begin{array}{l}3.17 \\
(0.240)\end{array}$ & $\begin{array}{l}4.01 \\
(0.135)\end{array}$ & - \\
\hline \multicolumn{8}{|l|}{ Risk Perception } \\
\hline Safe Risk (Ref) & - & - & - & - & - & - & - \\
\hline Unsafe Risk & $\begin{array}{l}1.33 \\
(0.765)\end{array}$ & $\begin{array}{l}1.32 \\
(0.763)\end{array}$ & $\begin{array}{l}2.30 \\
(0.284)\end{array}$ & $\begin{array}{l}2.34 \\
(0.273)\end{array}$ & $\begin{array}{l}2.42 \\
(0.252)\end{array}$ & - & - \\
\hline \multicolumn{8}{|l|}{ Attitude } \\
\hline Safe Attitude (Ref) & - & - & - & - & - & - & - \\
\hline Unsafe Attitude & $\begin{array}{l}2.91 \\
(0.147)\end{array}$ & $\begin{array}{l}2.92 \\
(0.141)\end{array}$ & $\begin{array}{l}3.20 \\
(0.081)\end{array}$ & $\begin{array}{l}3.18 \\
(0.082)\end{array}$ & $\begin{array}{l}3.27 \\
(0.072)\end{array}$ & $\begin{array}{l}4.01 \\
(0.028)\end{array}$ & $\begin{array}{l}3.61 \\
(0.039)\end{array}$ \\
\hline \multicolumn{8}{|l|}{ Years of Driving } \\
\hline$\leq 2$ years $($ Reference $)$ & - & - & - & - & - & - & - \\
\hline$>2$ years & $\begin{array}{l}6.52 \\
(0.009)\end{array}$ & $\begin{array}{l}6.50 \\
(0.006)\end{array}$ & $\begin{array}{l}5.53 \\
(0.007)\end{array}$ & $\begin{array}{l}5.58 \\
(0.007)\end{array}$ & $\begin{array}{l}6.12 \\
(0.003)\end{array}$ & $\begin{array}{l}6.32 \\
(0.003)\end{array}$ & $\begin{array}{l}6.35 \\
(0.002)\end{array}$ \\
\hline
\end{tabular}

or stationary. One interesting insight was that this was thought to be more prevalent in the younger generation of drivers, because they have acquired a "reflex" for automatically answering ringing cell phones in any situation, whether driving or not. Millennials in particular have answered their phones the instant they rang, or read a message as soon as it arrived, a habit which was unconsciously imbibed even while driving.

One example of when cell phones will be avoided during driving was when in-laws are in the vehicle to 
make them feel safe. Driving up a steep incline, or dangerous road conditions, e.g. down the side of a mountain, were just a few of the situations when cell phones were not used.

3.1.5 Risk Perceptions of Cell Phone Use while Driving

The most dangerous consequence of distracted driving is of being involved in a road traffic crash, a fact recognized by most in the group. Environmental or weather conditions, experience, and driving skill are all relevant to the potential hazards when engaging in distracted driving. Inclement weather or poorly lit roads could impair the vision of the driver, and the inherent risk and probability for an accident could even be higher for newly qualified drivers.

3.1.6 Attitudes towards Cell Phone Use while Driving

Being aware of the probable danger of distracted driving did not deter most of the drivers from using their handsets. The majority did not use their phones when driving with a significant person in their lives, such as spouse, parents or children. Designating another passenger to answer phone calls or texts was one safety strategy. However, it was sometimes inevitable to use the navigation apps.

3.1.7 Opinions on the Law on "Anti-Distracted Driving" and Its Enforcement

All agreed that drivers engaging in mobile phone use when driving should be penalized, but all also noted that the current laws on this risky behavior were quite lax in their implementation, and enforcement was not as strict as it should be. A higher and a stiffer penalty should be imposed if violations result in sizeable damage or loss of lives. Differing opinions on possible exemptions were elicited, as most say that it must be employed objectively across all violators, although doctors should be given special consideration, especially when attending to urgent calls. Most thought that hands-free devices, like earphones, Bluetooth, and voice-to-text/call apparatus were safer methods of using handheld phones while driving because these devices did not impair drivers cognitively. They believed that most can get away with traffic violations, and using darkly tinted cars was one way of evading traffic enforcers. There was a pervading perception that laws in the country were generally poorly implemented and less exacting.

3.1.8 Recommended Countermeasures against Distracted Driving Mainly due to Cell Phone Use

Suggested strategies include school-based measures, advertisements, and driving license regulation and technology. Education is required to instill public and road safety at an early stage. It is also essential to influence more senior and future road users. Another strategy is through advertising. The use of quadruple media, e.g., broadcasting, print, radio and social media, in depicting the dangers resulting from distracted driving may help road users realize its seriousness. This could, in turn, influence them to practice safe driving. The social networking sites were cited as major portals that could efficiently reach target audiences, such as the gadget-using millennials and novice drivers, through the use of viral videos of the catastrophic effects of risky driving practices. The "FB (Facebook) psychology" could be one measure to have a major effect on internet users. Viral videos on FB showing the 'drama' of the disastrous consequences of distracted driving could prove useful in conveying road safety messages. However, for drivers who may not have access to the internet or are not social media savvy, such as public or modified transport drivers (e.g., jeepneys, pedicabs, tricycles, etc.), signage on areas where they converge, such as eateries or jeepney terminals, should be placed warning them of the penalties and potential post-crash scenarios.

Stringent screening of prospective drivers should be enforced when securing driver's licenses, ensuring full recognition of road safety policies and traffic regulations. One proposed strategy is to increase road safety awareness by obligatory attendance to tailored lectures conducted by mandated traffic regulatory agencies e.g. the land transportation office, during 
periods of license renewal. Technology can also be used to catch violators of traffic laws. High definition cameras that can penetrate heavily tinted vehicles should be positioned in strategic places. A unique futuristic proposal entailing car engineering is to allocate a spot for telecommunications devices on the driver's side. When a gadget or phone is placed in this specially allocated carrier, it will automatically close, making access impossible while the car engine is running.

\section{Discussion}

The digital age has drastically escalated the possession and use of electronic gadgets. Farmer et al. in 2010 reports that drivers under 30 years old are likely to be distracted $16 \%$ of the time while driving [19]. Current investigation shows no significant difference in overall risk perceptions among drivers using a mobile phone from those who do not. Interestingly, a significant association has been noted concerning the perception of drivers using a cell phone: that hands-free devices are safer to use when driving. Compelling research evidence indicates that conversations on cell phones whilst driving, whether handheld or hands-free, increase the risk of injury and property damage crashes fourfold [5, 20]. Many drivers mistakenly consider talking on a hands-free cell phone safer than on a handheld phone [21]. These devices are erroneously seen as the safer solution to the risks of distracted driving because they help remove two apparent risks - the visual, looking away from the road, and the manual, taking one's hands off of the steering wheel. However, hands-free devices do not eliminate cognitive distraction, which can occur when the driver veers his mind off the road. Distracted drivers experience what researchers call inattention blindness, which has been compared to tunnel vision. They may be looking through the windshield, but their brains fail to process everything in the roadway environment that is necessary to monitor their surroundings sufficiently, identify potential hazards and respond to unexpected dangers on the road [22]. Using hands-free phones is more likely to cause drivers to miss relevant objects both in high and low places; this will certainly render them incapable of paying attention to more critical road details [23].

Most individuals recognize when they are visually or mechanically distracted and will usually disengage from these activities once they are fully aware. On the other hand, people are ordinarily unaware when distracted cognitively, such as conversing on the phone, resulting in increased in risk exposure time. Added to the dangers of hands-free phone use are the findings that this led to: an increase in reaction time in braking vehicles [24], to missing visual cues critical to safe navigation [25] and to lowered performance in safety tasks, such as peripheral visual checking and monitoring visual instruments such as the rear view and side mirrors [26].

The staggering prevalence of cell phone use of $90.68 \%$ in this study only reinforces the widely reported use of mobile phones while driving. An observational study undertaken in Australia confirms that young drivers (under 30 years) use mobile phones more often than middle-aged and older drivers (over 30 years old) while driving [27]. Driver distraction has already joined the ranks of alcohol and speeding as leading causes of fatal and serious road injury crashes. In 2010 the National Safety Council approximates that around $21 \%$ of all RTCs involved talking on cell phones, accounting for 1.1 million crashes the same year [28]. The results of the present study indicate that age, gender, annual family income, involvement in RTC and knowledge of Anti-DD Laws are not correlated with cell phone use; only driving experience of more than two years is significantly associated.

Overall, unsafe attitudes are significantly higher among drivers who use handsets while driving compared to those who do not $(p=0.007)$, and the same significant result is also seen on the use of handsets while driving, even when it is known to be dangerous $(p=0.003)$. Univariate logistic regression 
showed that driving experience of up to two years $(p=$ $0.001)$, risk perception $(p=0.046)$, and attitude ( $p=$ 0.005 ) as possible predictors, but further analysis using Multiple Logistic Regression revealed years of driving and attitude as the only significant predictors. These results are consistent with the conclusion of the ESRA (European survey on road users' safety attitudes) 2015, indicating attitude as having a substantial effect on the self-declared behavior of sending text messages and emails while driving [29]. The recent study by Oviedo-Trespalacios on the risk factors of mobile phone use while driving in Queensland also identifies attitude as a predictor of cell phone engagement. On the other hand, some research indicates that novice, inexperienced drivers are more likely to engage in DD [30] and most describe younger drivers to be particularly prone to distraction [31]. These results, however, are not replicated in this study. The educational background and medical occupation of the present study participants could have an effect on the number of years they have been driving. The majority have mid to higher-range family incomes and jobs requiring mobility; most would have the capacity to drive for longer compared to similarly aged individuals from the general public, thus explaining the high proportion $(87.59 \%)$ of longer driving experience coupled to the high self-reported cell phone use while driving.

To understand distracted driving in young adults, a behavioral modification framework that can explain such risky behavior is the TBP (theory of planned behavior). According to this model, intention is the most proximal determinant of behaviour, which is in turn influenced by attitude, subjective norm and PBC (perceived behavioral control). Attitude reflects an individual's favorable or unfavorable evaluation of performing a particular behavior; subjective norm refers to the social pressure a person feels in performing or refraining from a behavior and $\mathrm{PBC}$ pertains to self-efficacy or the degree to which one feels in engaging in a particular behavior [32]. The
TBP constructs have satisfactorily explained, as a theoretical framework, the high level of mobile phone use among drivers [33].

The respondents in this research keep a very tight and demanding schedule, being resident trainees in a busy tertiary hospital. The high prevalence of cell phone use while driving can be explained by their intention to remain connected to their peers, co-workers, patients and hospital superiors. This is shown by the overall unsafe attitude of using cell phones, despite awareness of its dangers and an unsafe risk perception of using hands-free devices to meet the need to continually communicate, even when driving. The presence of "in-laws" or significant others are the scenarios described in the FGD that will cause them to avoid distraction when driving, and which may represent the subjective norm they yield to. Their perceived behavioral control can be influenced by their medical education and training, family income, driving history, past involvement in RTC or previous experience with traffic law enforcers. Driving for more than two years and the general attitude towards cell phone use while driving are found to be significant predictors of this form of distracted driving.

The proposed measure for countering this risky driving behavior is a more strict enforcement of laws regarding distracted driving, as attitude is one of the significant predictors of cell phone use while driving. One of the novel suggestions for reducing mobile phone use is through the use of technology. A futuristic innovation in car engineering of allocating a specialized gadget carrier inside the vehicle that will automatically limit access while the engine is running is well worth considering. This could reduce mobile phone and other electronic gadget usage while the vehicle is still moving. Another recommended technological approach is to develop a handset with a built-in "driving mode" similar to the "flight mode" integrated into most smartphones. This new mode will, once in use, disable all texting and answering functions of the phone, and will also automatically send a 
message or a signal to any caller that the receiver on the other end is driving and unavailable.

These distractions while driving are fast becoming ubiquitous and socially acceptable, turning such behavior into a social norm. The "reflex to answer a cell phone the moment it rings", mentioned in the FGD, can be explained by the feeling of many young adults of the need to "stay connected", which in turn has influenced the routines in their daily lives, including driving practices. The habit of young drivers of checking their phones remains a major challenge for road safety authorities [34]. They no longer differentiate the setting they are in; these drivers answer calls or messages instinctively. This is certainly evident in this study, with a very high prevalence of cell phone use while driving; that is also echoed in the FGD. A possible behavioral modification approach is to place thematic advertisements in quadruple media identifiable to the target audience. Identification is an important element of testimonials, and can be used in commercials, as it relies on an individual connecting at a deep emotional level with a "character", and with suggestions that lead to positive behavioral change [35]. By combining the strategies of identification and placing a social stigma on texting and cell phone use while driving, similar to other risky driving practices such as drunk driving or speeding, a stronger message to offending drivers will be conveyed. This approach intends to shift the social acceptance of driver distraction towards rejection, increasing the awareness of the ill-effects of handset use while driving, and thus increasing safe driving performance.

A possible limitation of this research is in under-reporting of risky distracted driving, as it is seen to be unlawful and socially undesirable despite employing anonymity in data gathering. The use of the self-reported questionnaire to determine the level of cell phone use while driving may not be fully reliable in measuring actual use and practice. The survey is also limited to the driving population of resident trainees in a tertiary hospital situated in an area considered to have high-density traffic. The generalizability of the results is thus restricted, and caution in applying them to other drivers in other parts of the country, or to the general population, is advised. Future research may perhaps consider other groups of drivers in a different environment in order to overcome sampling population constraints.

\section{Conclusion}

The high prevalence of cell phone use (texting, reading a text, calling or receiving calls) in the present study provides support for the findings of most researchers on this form of distracted driving. Although there was no significant difference in the overall risk perception among those using a mobile phone from those who do not, a significant association was noted on the perception that hands-free devices are safer to use when driving. This risk perception is considered unsafe by most studies. Overall, an unsafe attitude is higher among drivers operating mobile phones while driving, and the same significant result is seen on the unsafe attitude of using handsets, even when drivers are aware of its dangers. Driving experience of more than two years and attitude are the only significant predictors. Recommended countermeasures to such risky driving behavior include placing a social stigma on distracted driving through quadruple media advertisements, innovations in car engineering, the development of built-in telecommunications hardware and, lastly, a more strict and consistent enforcement of traffic laws.

\section{Acknowledgments}

To Mr. Orlando Alba, my heart appreciation for all the help in the statistical analysis, to the Department of Health Promotion and Education-UP College of Public Health and Department of Emergency Medicine-UP College of Medicine for the support in accomplishing this study.

\section{References}

[1] WHO. 2017. "Road traffic injuries-Fact Sheet." Geneva, 
Switzerland. Accessed $30 \quad$ Sept 2017. http://www.who.int/mediacentre/factsheets/fs358/en/.

[2] CDC. 2016. "Distracted Driving." Centers for Disease Control and Prevention. Accessed 27 March 2017. https://www.cdc.gov/motorvehiclesafety/distracted_drivi ng/index.html.

[3] NHTSA. 2014. "Distracted Driving: Facts and Statistics." National Highway Traffic Safety Administration. Accessed 20 February 2017. https://www.distraction.gov/ stats-research-laws/facts-and-statictic.html.

[4] WHO. 2011. "Mobile Phone Use: A Growing Problem of Driver Distraction." Geneva, Switzerland. Accessed 30 Sept 2017. http://www.who.int/violence_injury_ prevention/publications/road_traffic/distracted_driving/en /index.html.

[5] McEvoy, S., Stevenson, M., McCartt, A. et al. 2005. "Role of Mobile Phones in Motor Vehicle Crashes Resulting in Hospital Attendance: A Case-Crossover Study.” BMJ 331: 7514.

[6] Strayer, D., Drews, F., and Crouch, D. 2006. "A Comparison of the Cell Phone Driver and the Drunk Driver." Human Factors 48: 382-91.

[7] Horey, W., and Wickens, C. 2006. "Examining the Impact of Cell Phone Conversations on Driving Using Meta-analytic Techniques." Human Factors 48 (1): 196-205.

[8] Hendrick, J., and Switzer, J. 2007. "Hands-free versus Hand-Held Cell Phone Conversation on a Braking Response by Young Drivers." Perceptual and Motor Skills 105 (2): 514-22.

[9] NHTSA. 2014. "Distracted Driving: facts and statistics." National Highway Traffic Safety Administration. Accessed 27 Feb 2017. https://www.distraction.gov/ stats-research-laws/facts-and-statictic.html.

[10] Sullman, M. 2012. "An Observational Study of Driver Distraction in England." Transportation Research Part F 15: 272-8

[11] PCHRD. 2014. "Message Sent: Cell Phone Distractions can Kill.” PCHRD. Accessed February 27, 2017. http://www.pchrd.dost.gov.ph/index.php/news/library-hea lth-news/1173-message-sent-cell-phone-distractions-cankill.

[12] Nurullah, A., Thomas, J., and Vakilian, F. 2013. "The Prevalence of Cell Phone Use While Driving in a Canadian Province." Transportation Research Part F: Traffic Psychology and Behaviour 19: 55-62.

[13] RA 10913. "Anti-Distracted Driving Act." Senate of the Republic of the Philippines. Accessed 27 February 2017. https://www.senate.gov.ph/republic_acts/ra\%2010913.pdf.

[14] Harrison, M. 2011. "College Student's Prevalence and Perceptions of Text Messaging while Driving." Accident Analysis and Prevention 43: 1516-20.
[15] Bergmark, R., Giklich, E., Guo, R., and Gliklich, R. 2016. "Texting while Driving: The Development and Validation Driving Survey of the Distracted Driving Survey and Risk Score among Young Adults." Injury Epidemiology 3: 7.

[16] Womack, K. 2013. Understanding and Addressing Distracted Driving in Texas. Texas: United Services Automobile Association.

[17] National Highway Traffic Safety Administration. 2011. "Traffic Safety Facts: Driver Electronic Device Use in 2010." Accessed February 20, 2017. http://www.distraction.gov/download/research-pdf/8052 TSF_RN_DriverElectronicDeviceUse_1206111_v4_tag.p df.

[18] Governor's Highway Safety Association. 2010. "Curbing Distracted Driving." Accessed 15 Mar 2017. http://www.ghsa.org/html/publications/survey/distraction 2010.html.

[19] Farmer, C., Braitman, K., and Lund, A. 2010. "Cell Phone Use while Driving and Attributable Crash Risk." Traffic Inj Prev 11: 466-70.

[20] Redelmeier, D., and Tibshirani, R. 1997. "Association between Cellular-Telephone Calls and Motor Vehicle Collisions." New England Journal of Medicine 336 (7): 453-8.

[21] AAA Foundation. 2008. "Cell Phones and Driving: Research Update.” Accessed 15 March 2017. https://www.aaafoundation.org/sites/default/files/CellPho nesandDrivingReport.pdf.

[22] Maples, W., DeRosier, W., Hoenes, R., Bendure, R., and Moore, S. 2008. "The Effects of Cell Phone Use on Peripheral Vision." Optometry. Journal of the American Optometric Association 79 (1): 36-42.

[23] Strayer, D., Cooper, J., and Drews, F. 2014. "What Do Drivers Fail to See When Conversing on a Cell Phone?" SAGE 79 (1): 157-65.

[24] Strayer, D., Drew, F., and Johnston, W. 2003. "Cell-phone Induced Failures of Visual Attention during Simulated Driving." Journal of Experimental Psychology: Applied 9 (1): 23-32.

[25] Drews, F., Pasupathi, M., and Strayer, D. 2008. "Passenger and Cell Phone Conversations in Simulated Driving." Journal of Experimental Psychology: Applied 14: 392-400.

[26] Harbluk, J., Noy, Y., Trbovich, P., and Eizenman, M. 2007. "An On-road Assessment of Cognitive Distraction: Impacts on Drivers' Visual Behavior and Braking Performance." Accident Analysis and Prevention 39 (2): 372-8.

[27] Young, K., Rudin-Brown, C., and Lenne, M. 2010. "Look Who's Talking! A Roadside Survey of Drivers' Cell Phone Use." Traffic Injury Prevention 11 (6): 555-60.

[28] Kolosh, K. 2012. "Summary of Estimate Model." National 
Safety Council. Accessed 30 September 2017. http://www.nsc.org/news_resources/Resources/Document s/NSC Estimate Summary.pdf.

[29] Areal, A. 2017. "Texting Distracted Driving Behaviour among European Drivers: Influence of Attitudes, Subjective Norms and Risk Perception." Prevencao Rodoviaria Portuguesa. Paris, France. Accessed 15 March 2017. www.esranet.eu.

[30] Oviedo-Trespalacios, O., King, M., Haque, M., and Washington, S. 2017. "Risk Factors of Mobile Phone Use while Driving in Queensland: Prevalence, Attitudes, Crash Risk Perception, and Task-Management Strategies." PLoS ONE 12 (9): e0183361.

[31] Hosking, S., Young, K., and Regan, M. 2009. "The Effects of Text Messaging on Young Drivers." Human Factors 51 (4): 582-92.
[32] Ajzen, I. 1991. "The Theory of Planned Behavior." Organizational Behavior and Human Decision Processes 50 (2): 179-211.

[33] Walsh, S., and White, K. 2007. "Me, My Mobile and I: The Role of Self and Prototypical Identity Influences in the Prediction of Mobile Phone Behavior." Journal of Applied Social Psychology 37: 2405-34.

[34] Turnbull, N., and Algie, J. 2017. “A qualitative Analysis of Young Driver's Perceptions of Driver Distraction Social Marketing Interventions." Paper presented on World Social Marketing Conference, Sydney, Australia.

[35] Hinyard, L., and Kreuter, M. 2007. "Using Narrative Communication as a Tool for Health Behaviour Change: A Conceptual, Theoretical, and Empirical Overview." Health Education and Behaviour 34 (5): 777-92. 